\title{
Sürdürülebilir Peyzaj Tasarım Kriterleri Doğrultusunda Sultanbeyli Gölet Parkı için bir Model Önerisi
}

\author{
Yasemin ŞENOL ${ }^{1}$, Alev P. GÜRBEY* \\ 1 İstanbul Üniversitesi-Cerrahpaşa, Lisansüstü Eğitim Enstitüsü, Peyzaj Mimarlı̆̆ı Anabilim Dalı, 34325, \\ İSTANBUL \\ 2 İstanbul Üniversitesi-Cerrahpaşa, Orman Fakültesi, Peyzaj Mimarlığı Bölümü, 34473, İSTANBUL
}

\begin{abstract}
Öz
Günümüzde hızla artan yapılaşma hareketleri, sanayileşme ve küresel ısınmanın etkisiyle doğal çevre ve ekolojik yapı bozulmaya başlamış, bozulan ekolojik yapı çevre sorunlarını da beraberinde getirmiştir. Kentlerin beton alanları ve geçirimsiz yüzeyleri giderek artmakla beraber yeşil alanları azalmıştır. Bunun sonucu olarak, sürdürülebilir bina uygulamalarının yanı sıra yeşil alanlarda da sürdürülebilirlik çalışmaları başlamıştır. Sürdürülebilir peyzaj alanları oluşturmak için doğal materyaller ve geri dönüşümlü malzemelerin kullanımıyla birlikte, su ve enerji etkin birçok sistemin beraber sağlanması gerekmektedir. Enerji etkin tasarımlarda da yenilenebilir enerji kaynakların kullanımı ana kriteri oluşturmaktadır. Bu çalışmada, Sultanbeyli Gölet Parkı için sürdürülebilir bir tasarım modeli oluşturulmuştur. İnşaat aşamasında başlayan sürdürülebilirlik kriterleri peyzaj uygulaması tamamlanana kadar geçen süreç için ele alınmıştır. Çalışma alanının doğal ve sosyo-kültürel peyzaj analizi yapılmış ve sürdürülebilir tasarım kriterleri ile oluşturulan örnek uygulamalar incelenerek mevcut tasarımla karşılaştırılmıştır. Getirilen öneriler kapsamında sürdürülebilir ilkeler doğrultusunda alan için yeni bir tasarım modeli oluşturulmuştur.
\end{abstract}

Anahtar Kelimeler: Sürdürülebilir Peyzaj Tasarımı, Su ve Enerji Etkinliği, Sultanbeyli Gölet Parkı, Yeşil Alan.

\section{A Proposed Model for Sultanbeyli Pond Park in Accordance with Sustainable Landscape Design Criteria}

\begin{abstract}
Today the natural environment and its constituent ecological structures have deteriorated due to a range of anthropogenic factors including human development and urbanisation. This deterioration in ecological structure has brought with it problems for humanity, especially in our cities. Concrete areas and other impermeable surfaces in cities have gradually increased at the expense of more natural 'greenspace', causing a range of impacts on the overall health of our environment. As a result, studies on the concept of 'green developments' and sustainable building practices have increased. This has included looking at the use of natural and recycled materials, sustainable landscape areas and water and energy-efficient systems. The use of renewable energy systems has become one of the key areas of focus in sustainable development and the main criterion in energy-efficient designs. In this study, a sustainable design model has been created for the Sultanbeyli Pond Park. Sustainability criteria were taken into consideration for a process that started during the construction phase and continued until the landscape application was completed. An analysis of natural and socio-cultural landscape features of the study area is made and we examine the current design against other examples of sustainable design criteria. Finally, we propose, through our analyses, a new model developed in the context of sustainable design principles.
\end{abstract}

Keywords: Sustainable landscape design, water and energy efficiency, Sultanbeyli pond park, green spaces. 


\section{Giriş}

20. yüzyılın en önemli kavramlarından biri sürdürülebilirlik olmuştur. Sürdürülebilirlik, mevcut kaynakların tükenmesine ve bozulmasına izin vermeden gelecek nesiller için bu kaynakları koruyup sürekliliğinin sağlanması olarak ifade edilmektedir (Atıl ve diğ., 2005). 1980'li yılların sonunda sürdürülebilirlik ile birlikte yeşil tasarım kavramı öne çıkmıştır. 1990’lı yıllardan günümüze kadar uzanan süreçte ise ekolojik mimarlığı da kapsayarak sürdürülebilir mimarlık anlayışı ortaya çıkmıştır (Pitts, 2003; Yurtsev, 2005; Ciravoğlu, 2006; Durmuş, 2009). Sürdürülebilir mimarlık, ekolojik tasarıma dayalı bir çevre yaratmayı ve devamlılığını sağlamayı hedeflemektedir. Yapı arazisi ve kaynakların etkin kullanımı, enerjinin etkin kullanımı, suyun etkin kullanımı, malzemenin etkin kullanımı, yapı içi konforu ve insan sağlığının gözetilmesi ile atık yönetimi gibi prensiplere dayanmaktadır (Şermet, 2017). Enerjinin etkin kullanımını amaç edinen peyzaj uygulamalarında; yenilenebilir enerji kaynaklarını kullanarak kendi enerjisini kendi üreten, geri dönüşümlü malzemelerden oluşan, bulunduğu yeşil çevreyi olabildiğince koruyan ve geri kazanım yöntemleriyle yağmur suyu ve gri suyu arıtıp yeniden kullanan sistemler önem taşımaktadır (Yurtsev, 2015). Enerji etkin peyzaj tasarımında su tüketiminin azaltılmasına yardımcı olan birçok yöntem bulunmaktadır. Yapılarda yağmur suyu ve gri su geri kazanım sistemlerini oluşturmak, enerji korunumlu ve düşük su tüketimli su tesisatı elemanları kullanmak, kurakçıl peyzaj (Xeriscape) alanlarına yer verilerek çim alanları olabildiğince azaltmak, alana kolay adapte olan doğal bitki türlerini kullanmak, yeşil parsellere yer verilmesi ve yağmur bahçelerinin oluşturulması vb. yöntemler başlıca çözümlerdir.

İnşaat sektöründe sürdürülebilirlik konularında yenilikçiliğe teşvik etmek için küresel veya ulusal ölçekte kullanılan birçok sertifikasyon sistemi bulunmaktadır (Gürbey ve Kanbur, 2020). 2009 yılında sürdürülebilir peyzaj alanları oluşturmak için Amerikan Peyzaj Mimarları Derneği (ASLA) tarafından yönetilen Sürdürülebilir SITES Girişimi adlı disiplinler arası bir ortaklık yeni bir derecelendirme sistemi oluşturmuştur. SITES sertifikalı projeler, sürdürülebilirliği binanın ötesinde tanımlamaktadır. Bu sertifikaya sahip alanlar; su tüketimini azaltmaya, yağmur suyu akışını filtrelemeye ve azaltmaya, doğal yaşam habitatı sağlamaya, enerji tüketimini azaltmaya, hava kalitesini iyileştirmeye, insan sağlı̆ııı iyileştirmeye ve dış mekan rekreasyon fırsatlarını arttırmaya yardımcı olmaktadır (Gürbey, 2020; Keskin, 2018). Peyzaj tasarımlarında sürdürülebilirliğin sağlanmasında; mikroklimatik verilerin değerlendirilmesi, yenilenebilir enerji kullanımı, suyun geri kazanılması, geri dönüşüm sistemlerinin oluşturulması, doğal kaynakların korunması ve mevcut bitki örtüsünün değerlendirilmesi önemli kriterleri oluşturmaktadır (Atıl ve diğ., 2005; Yaşar ve Düzgüneş, 2013).

$\mathrm{Bu}$ çalışmanın amacı, araştırma alanı olarak seçilmiş olan Sultanbeyli Gölet Parkını sürdürülebilir tasarım kriterleri doğrultusunda yeniden düzenleyerek, kendi kendine yetebilen bir parka dönüştürmektir. Bu kapsamda araştırma alanı sürdürülebilir uygulama örnekleriyle karşılaştırılmış, elde edilen bulgular sonucunda yeni bir tasarım modeli oluşturulmuştur.

\section{Materyal ve Metot}

\subsection{Materyal}

Araştırma alanı olarak seçilen Sultanbeyli Gölet Parkı, İstanbul ili Anadolu Yakası'nda bulunan Sultanbeyli ilçesi sınırlarında yer almaktadır. (Şekil 1). Sultanbeyli ilçesi açık alanlar açısından tüm İstanbul metropoliten alanı içindeki en yetersiz ilçe olarak göze çarpmaktadır. Söz konusu durumun, ilçenin bu güne dek düzensiz gelişmesi ile doğrudan ilişkisi bulunmaktadır (İBB, 2005).

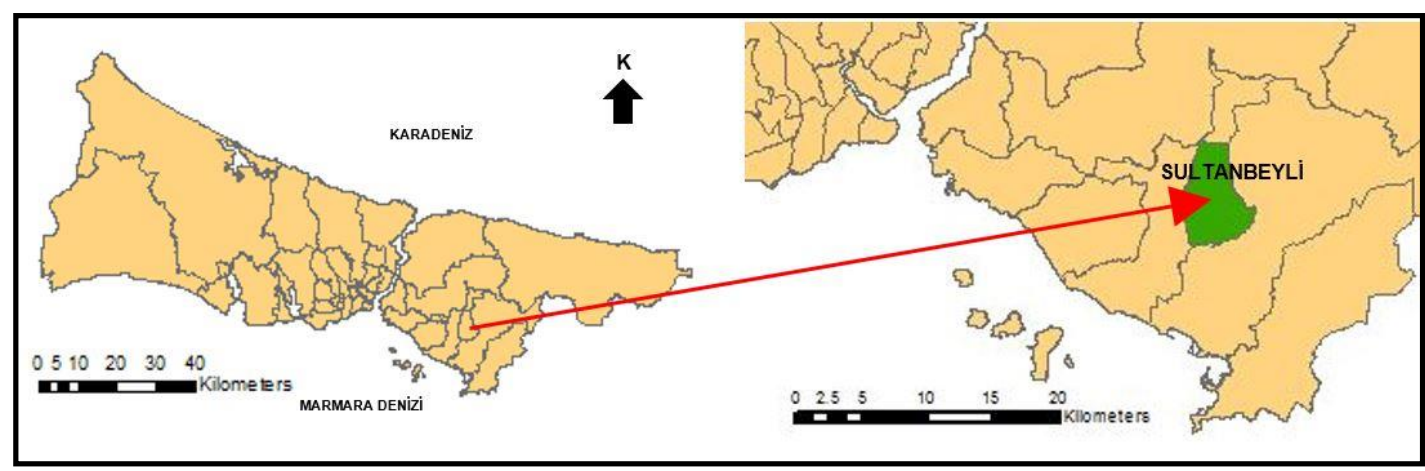

Şekil 1: Sultanbeyli ilçesinin konumu 
İlçe genelinde nüfus büyüklüğü ve yoğunluğu fazla olduğundan dolayı, kişi başına düşen yeşil alan miktarlarının da oldukça düşük olduğu görülmektedir. İlçeye bağlı tüm mahallelerde de kişi başına düşen yeşil alan miktarlarının oldukça düşük olması nedeniyle Sultanbeyli Gölet Parkı ilçe için oldukça önemli bir yere sahip bulunmaktadır (İBB, 2006). İstanbul Büyükşehir Belediyesi ile Sultanbeyli Belediyesi'nin ortaklaşa gerçekleştirdiği ve $140.000 \mathrm{~m}^{2}$ alana sahip Sultanbeyli Gölet Park1 2014 yılında hizmete açılmıştır (URL-1). Park içerisinde 36.000m²'lik alana sahip Sultanbeyli Göleti bulunmaktadır. Gölet aynı zamanda Ömerli Barajı su toplama havzası içindedir (Tezer, 2015) Aydos ormanlarından ve şehirden gelen yağmur suları gölette toplanıp, Ömerli barajına açılmaktadır (Şekil 2). Alanın sahip olduğu topoğrafik özellikler nedeniyle, Aydos ormanlarındaki fazla yağış suları gölete akmaktadır.

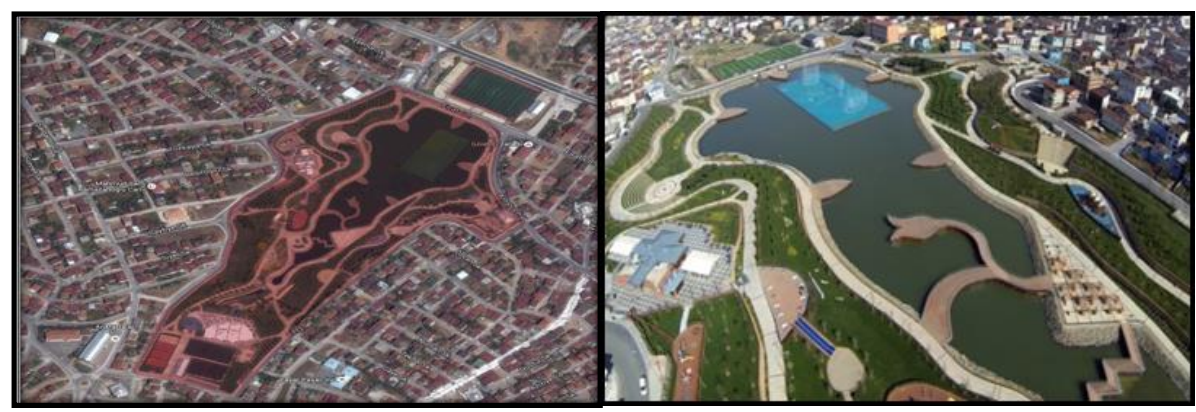

Şekil 2: Sultanbeyli Gölet Parkı (URL-2; URL-3)

\subsection{Metot}

Araştırmanın yöntemi, literatür taramasına ve örnek uygulamaların analiz edilmesiyle sonuçların değerlendirilmesine dayanmaktadır. Yazılı, görsel bilgi ve belgelerle birlikte birçok örnek uygulama incelenerek durum değerlendirmesi yapılmıştır (Şekil 3).

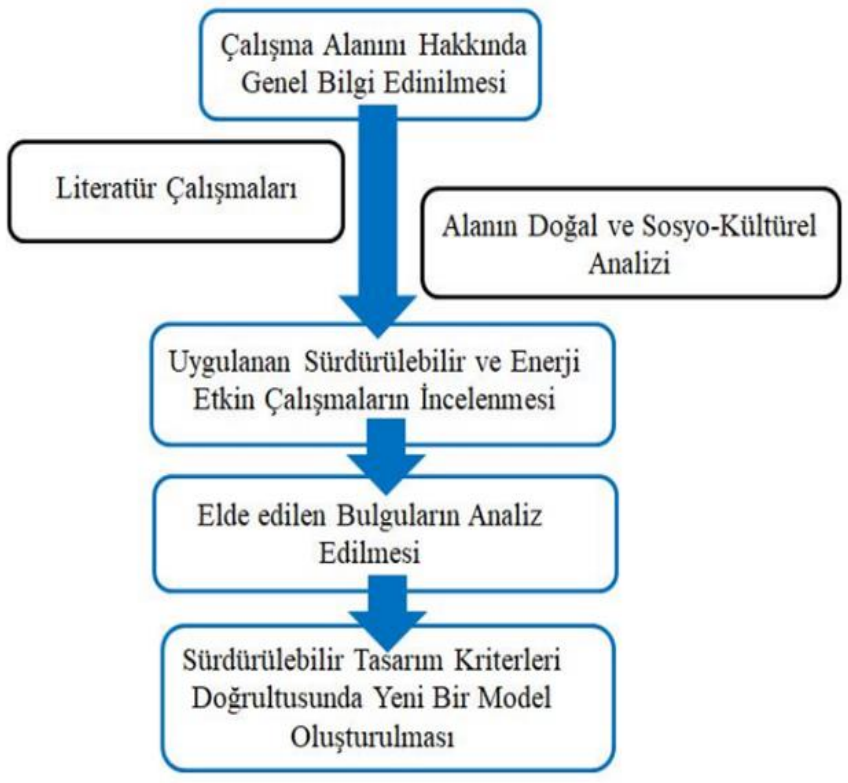

Şekil 3: Araştırma yöntem şeması

Araştırmada öncelikle alan çalışmaları (bilgi toplama, yerinde gözlem, kişilerle görüşme, fotoğraflama ve görselleştirme vb.) yapılmış ve dokümanlar oluşturulmuştur. Alandaki tüm fonksiyonlar, kentsel donatı elemanları, kullanılan malzemeler, mevcut topoğrafya çözümleri, sert ve yumuşak peyzaj alanları ile drenaj sistemleri detaylı şekilde incelenerek, fotoğrafları alınmıştır. Gerekli harita ve grafikler oluşturularak değerlendirmeler yapılmıştır. İlgili birimlerden vaziyet planı ve gerekli altlıklar temin edilmiştir. Araştırmanın son aşamasında sürdürülebilirlik ve enerji-su etkin peyzaj çalışmaları üzerine oluşturulmuş yerli ve yabancı birçok kaynak incelenmiştir. Sürdürülebilir tasarım kriterleri bu alan için irdelenirken, dünyadan örnek çözümlerle değerlendirmeler yapılmıştır. Alan bu kriterler doğrultusunda oluşturulan çizimlerle desteklenmiştir. 


\section{Bulgular}

\subsection{Sultanbeyli Gölet Parkının Önceki Kullanımı ve Mevcut Durum Analizi}

Park olarak hizmete açılmadan önce, içerisinde çevresindeki plansız yapılaşma sebebiyle kirlenmiş ve sadece sınırlı belediye hizmetlerinde kullanılabilen, birçok boğulma olayının yaşandığı bir gölete sahip atıl bir alan konumunda olan Sultanbeyli Gölet Parkı, yapılan düzenlenmeler sonrasında rekreasyon alanı olarak ilçenin çekim merkezi haline gelmiştir.

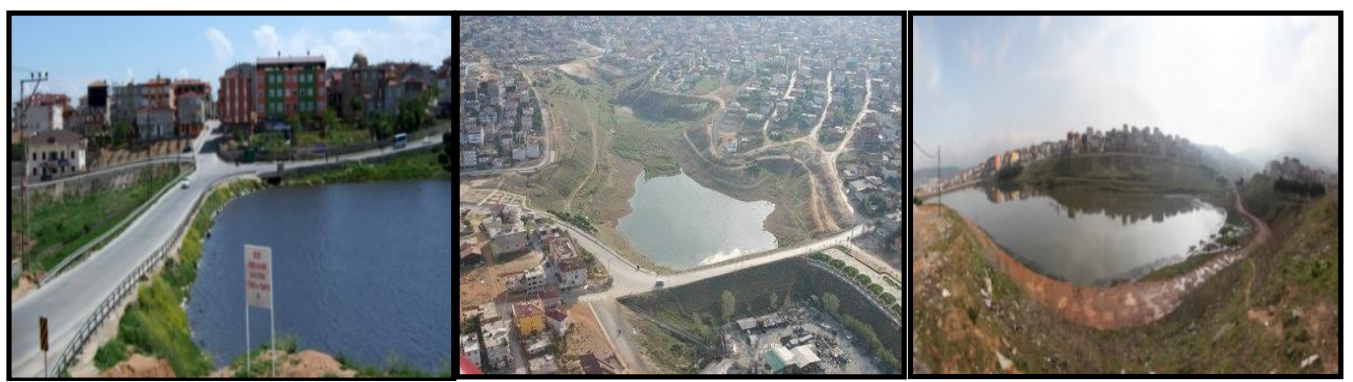

Şekil 4: Sultanbeyli Gölet Parkının önceki durumu (URL-4; URL-5).

Alanda, peyzaj uygulama çalışmalarına başlamadan önce göletin suyu boşaltılııș ve gölet dibinden 1500 kamyon balçık çıkarılmışıır. Islah çalışmaları kapsamında göletteki su derinliğinin düşürülmesi amacıyla 6000 kamyon grovat malzeme getirilmiştir. Mevcut tasarımda yaklaşık 1.5-2 metre derinlikte olan gölet tabanına beton dökülmüştür. Ardından peyzaj düzenlemelerine hazırlık olarak, altyapı ve sulama sistemleri yapılmıştır (URL-6). Proje; sosyal tesis, amfi tiyatrolar, gölet üstü ahşap teraslar, çocuk oyun alanı, kültür-fizik alanı, su parkı, piknik alanı, spor sahaları ve gölet üzerinde su gösteri alanı gibi fonksiyonlar içermektedir (Şekil 5, Tablo 1). Bitkisel tasarım uygulaması sonucunda alan mevcut haline getirilmiştir (URL-4) (Şekil 6).

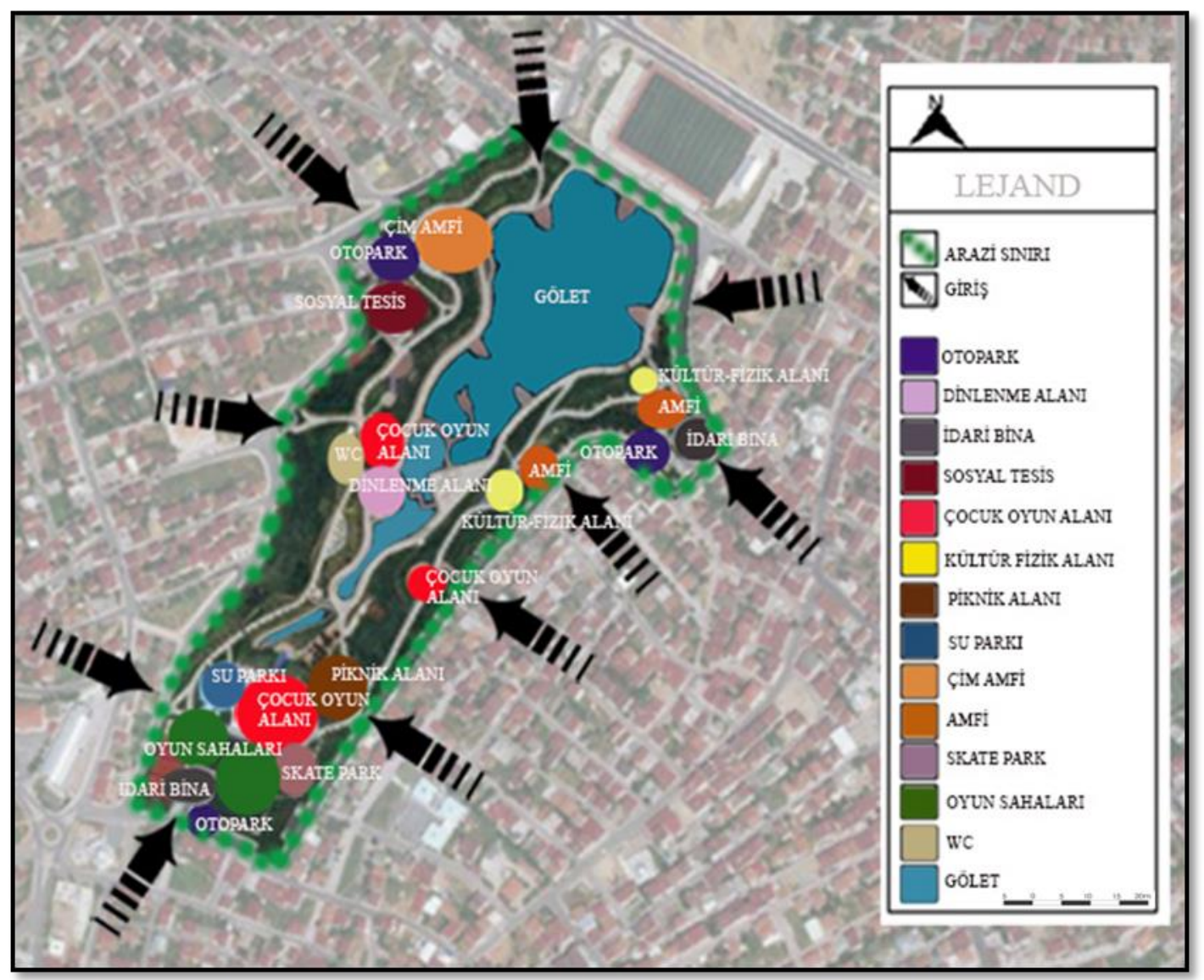

Şekil 5. Sultanbeyli Gölet Parkı mevcut alan kullanım paftası 
Tablo 1. Sultanbeyli Gölet Parkı fonksiyon alanları

\begin{tabular}{lc}
\hline FONKSIYON & BOYUT \\
\hline Gölet & $36.000 \mathrm{~m}^{2}$ \\
Sosyal Tesis & $2010 \mathrm{~m}^{2}$ \\
Amfi Tiyatro & $500 \mathrm{kişilik}$ \\
Amfi Tiyatro & $750 \mathrm{kişilik}$ \\
Çim Amfi Tiyatro & $1200 \mathrm{kişilik}$ \\
Gölet üstü ahşap teraslar & $2350 \mathrm{~m}^{2}$ \\
Çocuk Oyun Alanı & $6500 \mathrm{~m}^{2}$ \\
Kültür-Fizik Alanı & $560 \mathrm{~m}^{2}$ \\
Su Parkı & $740 \mathrm{~m}^{2}$ \\
Piknik Alanı & $4700 \mathrm{~m}^{2}$ \\
Futbol Basketbol Voleybol Tenis sahaları & $5800 \mathrm{~m}^{2}$ \\
\hline
\end{tabular}

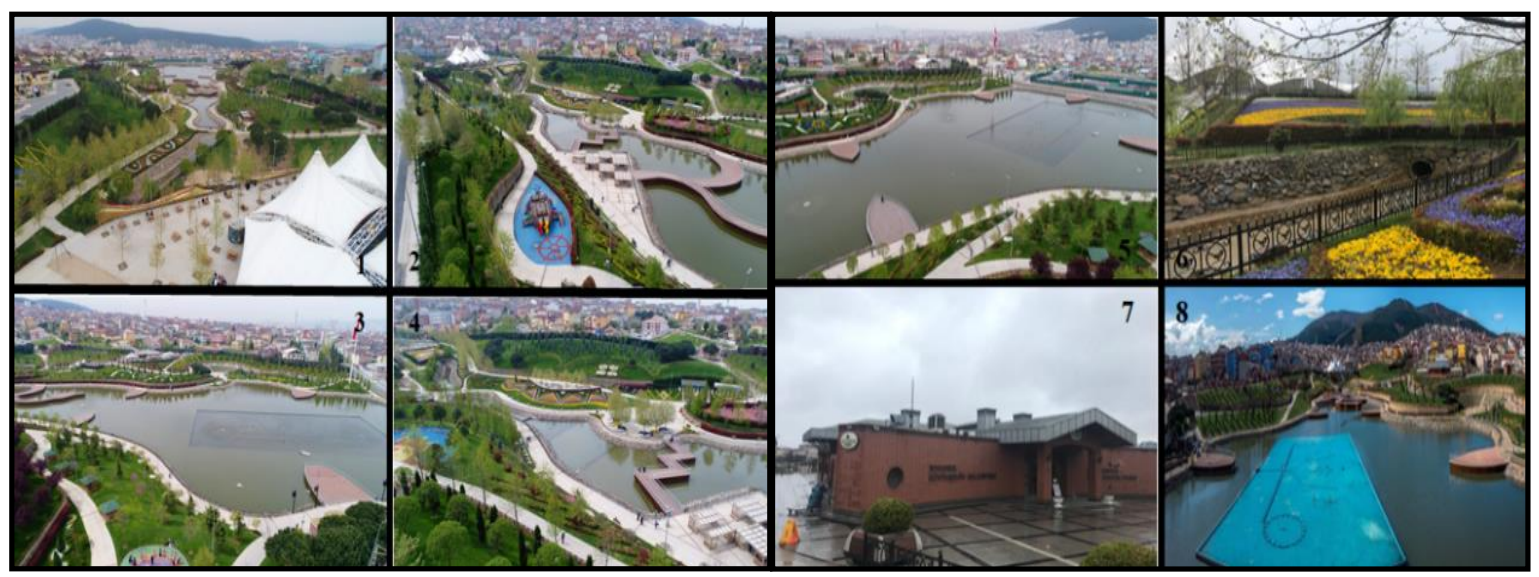

Şekil 6: Sultanbeyli Gölet Parkının genel görünümleri (1-Alanın güneyindeki asma-germe sistemden dinlenme alanları ve göletin görünümü 2-Alanın güneydoğusundan bakıldığında görülen çocuk oyun alanı ve teras üzeri dinlenme alanları 3-Alanın doğusundaki su gösteri alanının görünümü, 4-Alanın güneydoğusundan göletin ve terasların görünümü, 5-Alanın güneyinden gölete bakış 6-Alanın Güneybatısından bakıldığında görülen kanal 7Alandaki sosyal tesis 8-Alanın kuzeyinde gölet üzerinde bulunan su gösteri alanı).

\subsection{Sultanbeyli Gölet Parkının Mevcut Tasarımının İrdelenmesi ve Sürdürülebilir Tasarımına Yönelik Öneriler}

\subsubsection{Yapısal Tasarımda Tespit Edilen Sorunlar ve Çözüm Önerileri}

Parkı içinde bir adet engelli araç parkı olmak üzere toplam 53 araç kapasiteli 3 adet otopark bulunmaktadır. Park çevresinde ise 4 adet cep otoparkı bulunmaktadır. Ayrıca parkta 10 birimlik bisiklet parkı bulunmaktadır. Mevcut otoparklar, alanın kullanıcı kapasitesi için yeterli değildir. Engelliler için ayrılan bölümler arttırılmalıdır. Otoparkların zemin döşemesi süpürgeli betondur (Şekil 7). Otoparklar geçirimli yüzeylere (ekogrid üzeri çim ve mıcır, çim taşı, geçirimli asfalt vb.) dönüştürülmelidir (Öztürk, 2017; Tuncay, 2017). Büyük sert zeminlerden oluşan otoparkların önünde hem görüntüyü yumuşatmak hem de geçirimliliği arttırmak adına yağmur bahçesi görevi gören yeşil parseller bırakılmalıdır (Saygın, 2017).

Çocuk oyun alanlarının tümünde zemin döşemesi olarak dökme kauçuk kullanılmıştır ve büyük bir kısmının yıprandığı görülmektedir (Şekil 8). Sağlık açısından zararları da düşünülürse, çocuk oyun alanlarında yapay materyaller yerine doğal materyaller (ağaç kabuğu, sıkıştırılmış talaş, mıcır, kum, toprak vb.) kullanılmalıdır (Türkan ve Önder, 2011; Taştepe vd., 2016). Alanlar, yaş gruplarına göre düzenlenmeli ve engelliler için oluşturulan oyun grupları mutlaka bu oyun alanları içinde yer almalıdır (Erkan, 2011; Küçükyağcı vd., 2015; Özdemir, 2017). Bir oyun alanında kullanılmış bir özellik olmasına rağmen, gerek kaydırak gerekse tırmanma duvarı olarak diğer oyun alanlarında da alanın doğal topoğrafyasından yararlanılmalıdır. Böylelikle, geleneksel oyun gruplarının da dışına çıkılmış olur. Özellikle çevre bilincini arttıracak, yenilenebilir enerji ve geri dönüşüm hakkında eğitici ve öğretici oyun gruplarına yer verilmesi sağlanmalıdır. Çocuk oyun alanlarında ahşap donatılarda 
dayanıklılığı nedeniyle 1.sınıf emprenyeli Sibirya çamı tercih edilmelidir. Alanda estetik bir görüntü sağlamak amacıyla boya kullanılmamasına dikkat edilmiştir. Bazı oyun gruplarının alana monte edilmesinde, doğa dostu olması sebebiyle beyaz çimento kullanılmalıdır. Çelik malzeme olan kısımlarda ise paslanmaz çelik tercih edilmelidir.

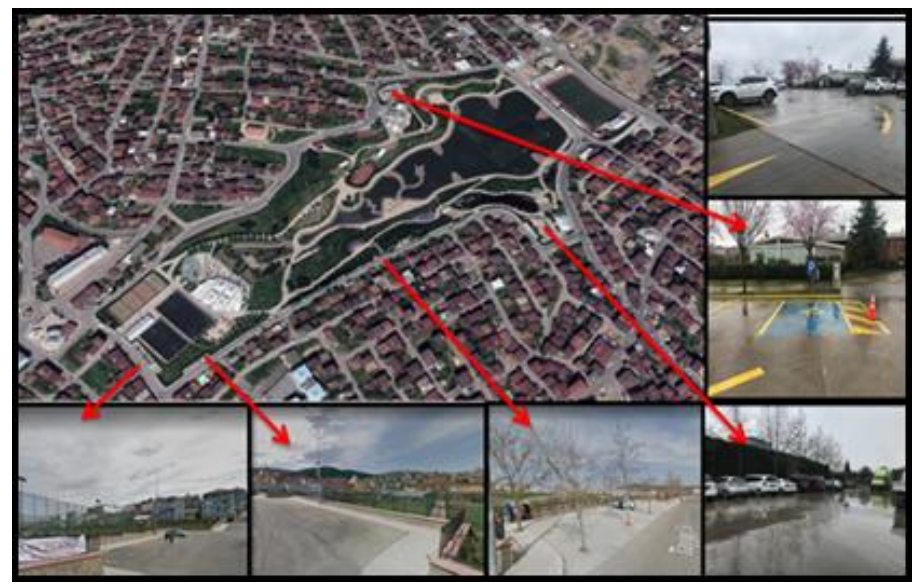

Şekil 7: Sultanbeyli Gölet Parkındaki mevcut otoparklar

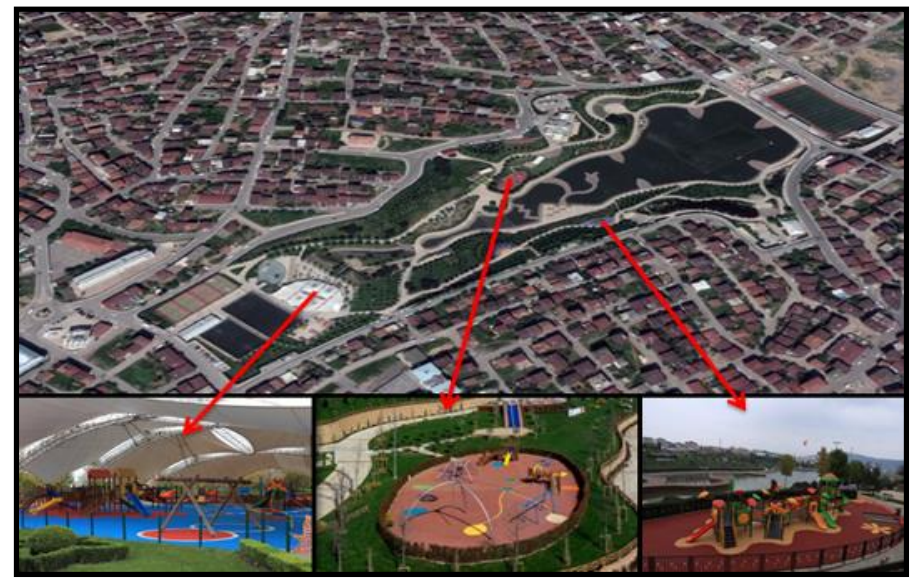

Şekil 8: Sultanbeyli Gölet Parkındaki mevcut çocuk oyun alanları

Alandaki su oyun parkı geçirimsiz yüzey üzerinde oluşturulmuştur ve bu alanda suyun geri dönüşümü sağlanmalıdır (Şekil 9). Su oyun parkı çocukların dahil olacağı şekilde kendilerinin suya yön verdiği ekipmanlarla desteklenmelidir. Doğal ortam ile bir bütün halinde su ögesine yer verilmelidir.

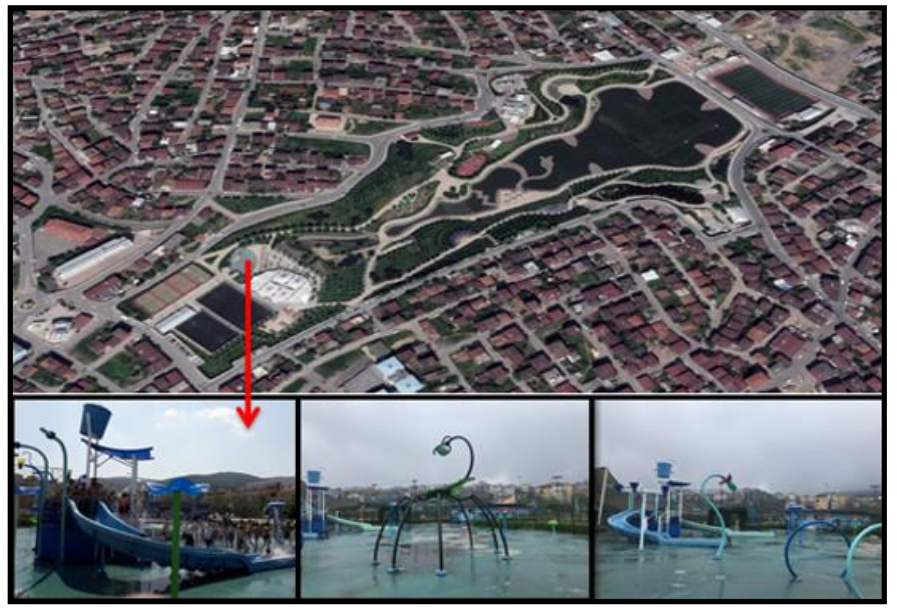

Şekil 9: Sultanbeyli Gölet Parkındaki mevcut su oyun parkı 
Kültür-fizik alanları kauçuk üzerine monte edilmiştir (Şekil 10). Konumu itibariyle parkı karşılayan meydanlarda oluşturulmuştur. Aksine, yürüyüş yollarının kenarlarına belirli aralıklarla ve geçirimli yüzeyler üzerine (ağaç kabuğu, sıkıştırılmış kiremit, çakıl, ekogrid üzeri çim vb.) yerleştirilmelidir. Kültür-fizik aletlerinin dışında her yaş grubunun kullanabileceği kol-kas sistemini geliştiren ekipmanlar da (asılma, denge, tırmanma vb.) oluşturulmalıdır. Engellilere yönelik ekipmanlara da yer verilmelidir. Engelli bireyler için tekerlekli sandalyelerin kolay hareket etmesini sağlamak için doğal materyaller bazı bölümlerde sıkıştırılarak kullanılmalıdır.

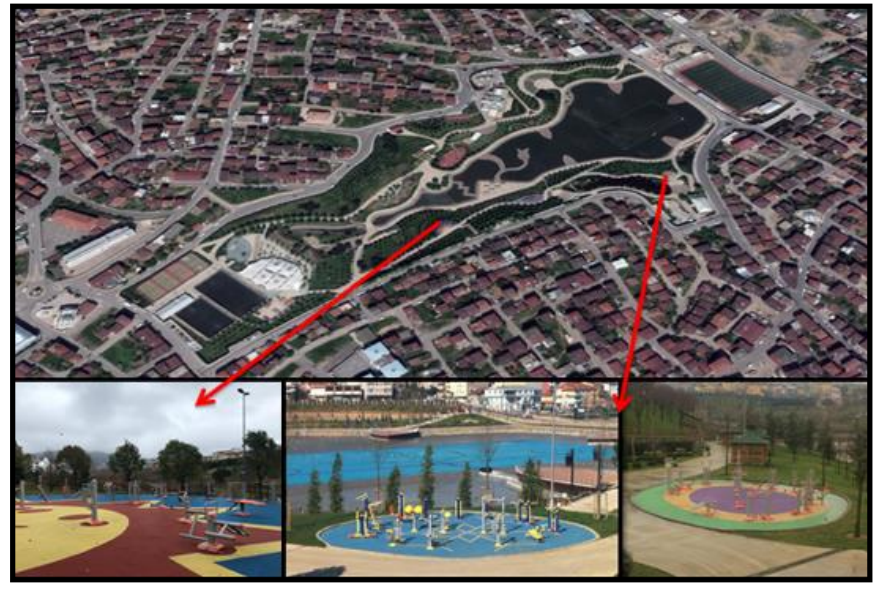

Şekil 10: Sultanbeyli Gölet Parkındaki mevcut kültür-fizik alanları

Basketbol, tenis ve voleybol sahalarında drenaj sorunu gözlenmiştir. Alandaki sahaların üzerleri açık olduğu için yağışlı havalarda kullanılamamaktadır (Şekil 11). Yağışlı günlerde de kullanıma açmak için sahaların bir kısmının üzeri kapatılmalıdır. Sürdürülebilir park konseptine uygun olarak oluşturulacak çatı sisteminde fotovoltaik paneller ve yağmur suyu toplama havuzları oluşturulmalıdır. Çatıda oluşturulan yağmur toplama havuzları ile yağmur suları toplanıp, direk yağmur oluklarından geçip, filtrelenerek ana depoya verilmelidir (Yoneda, 2013).

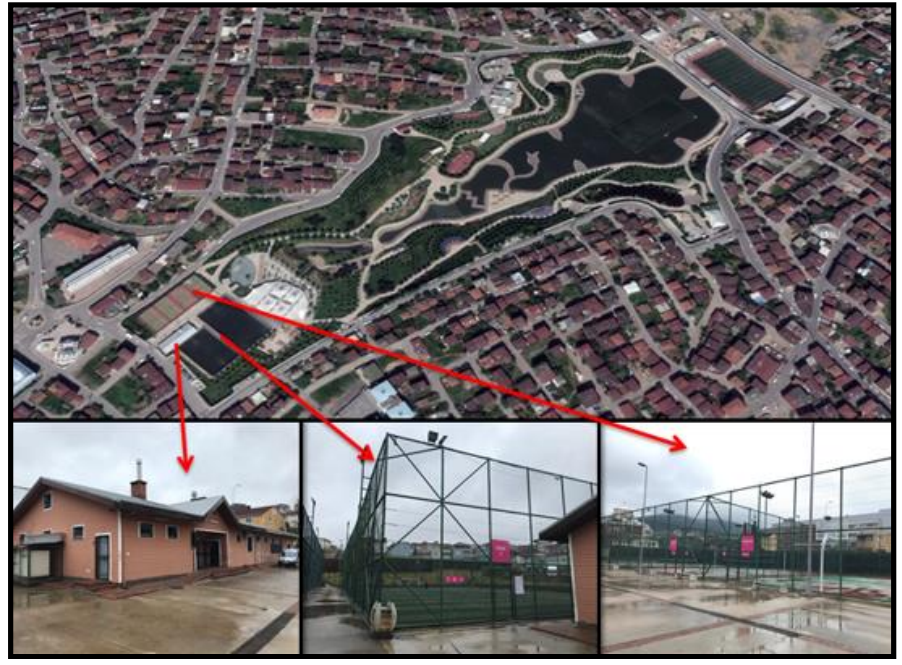

Şekil 11: Sultanbeyli Gölet Parkındaki mevcut spor sahaları

Skate park tasarımı, sınırları olan beton dökülmüş dikdörtgen bir alan olmak yerine; arazinin eğimiyle uyumlu, yeşil alanı da içine alan yürüyüş yollarıyla alana bağlanan bir fonksiyon olarak tasarlanmalıdır (URL-7). Skate park ve kaykay modülleri geçirimli betondan yapılarak yağmur suyunun birikmesi önlenmelidir (Şekil 12). 


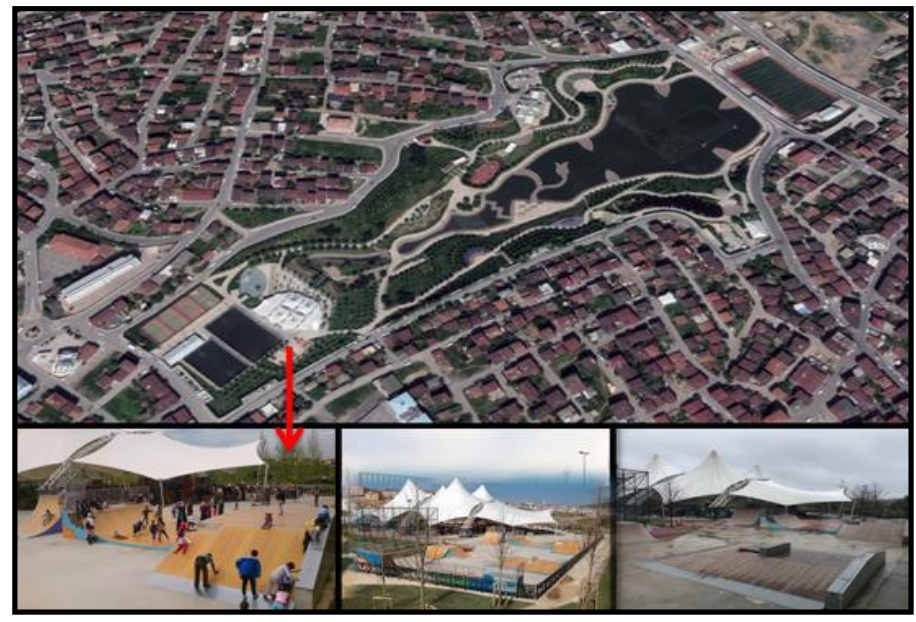

Şekil 12: Sultanbeyli Gölet Parkındaki mevcut skate park.

Drenaj problemi görülen piknik alanı güney bölüme alınarak, üzerleri fotovoltaik panellerle kapatılmalıdır (URL8). Güneş enerjisinden elde edilen elektrik enerjisi, park içindeki yapıların aydınlatılmasında ve sıcak su elde etmesinde kullanılmalıdır (Şekil 13). Yer döşemesi geçirimli malzeme seçilerek, alandaki drenaj sorunu çözülmelidir. Biriken su için yağmur oluklarına ve yeşil alana doğru eğim verilmelidir.

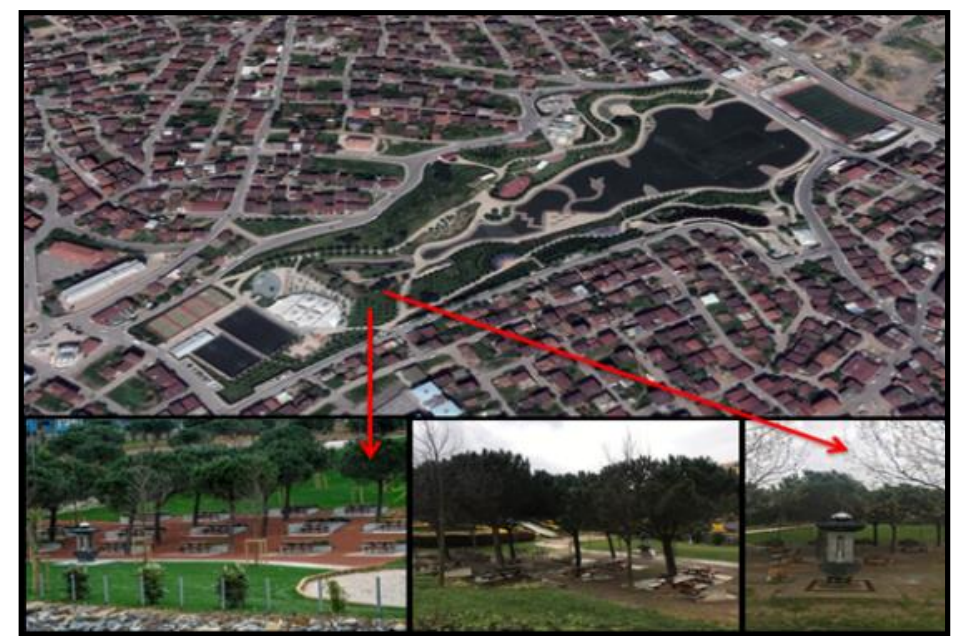

Şekil 13: Sultanbeyli Gölet Parkındaki piknik için ayrılmış alan

Mevcut teraslar sadece gezinme amaçlıdır, oturma birimi ve gölge yaratacak donatılar kullanılmamıștır (Şekil 14). Seyir teraslarına yenilenebilir enerji kaynaklarının destekleyen çözümler getirilmelidir. Güney cephelerde fotovoltaik panellere sahip oturma birimleri oluşturulmalıdır. Su etkin tasarım amacıyla da yağmur suyunun toplanmasına imkan veren oturma birimleri tercih edilmelidir. Teraslara fonksiyon kazandırmak için bir bölümde ipli oyun iskelesi oluşturularak, alana hareket kazandırılıp suyla kullanıcıyı yakınlaştırmayı amaçlanmaktadır. Mevcutta seyir terasları kompozit ahşap ile kaplanmıştır. Sürdürülebilir bir malzeme olduğu için oluşturulacak tasarımda ahşap kullanılacak kısımlarda kompozit ahşap tercih edilecektir. 


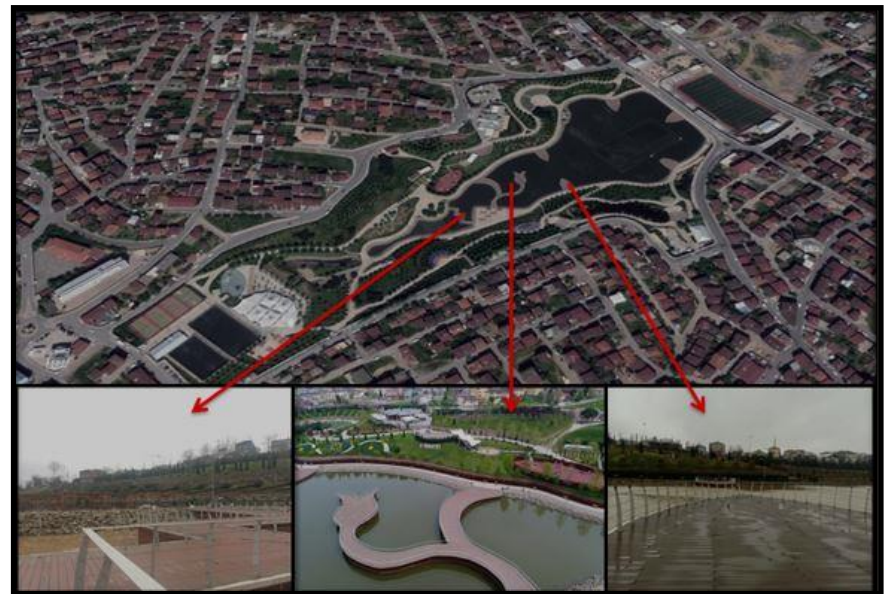

Şekil 14: Sultanbeyli Gölet Parkındaki gölet üzeri ahşap teraslar

Alanda oluşturulan Amfi tiyatroların bazıları alan girişini karşılamaktadır (Şekil 15). Engellilerin kullanabileceği rampa çözümleri ile beraber oluşturulmalıdır. Erişilebilirlik, park boyunca devamlılık sağlayacak şekilde kılavuz iz taşları veya kabartmalı yüzeylerle çözülmelidir. Alan çok eğimli olduğu için, birkaç giriş için özel rampa çözümleri yer almalıdır. Amfi tiyatroların yapımında geçirgen ve gözenekli bir malzeme olan kireç taşı kullanılmalıdır. Gerekli yerlerde gabyon tip basamaklar ile doğal bir görüntü sağlanmalıdır.

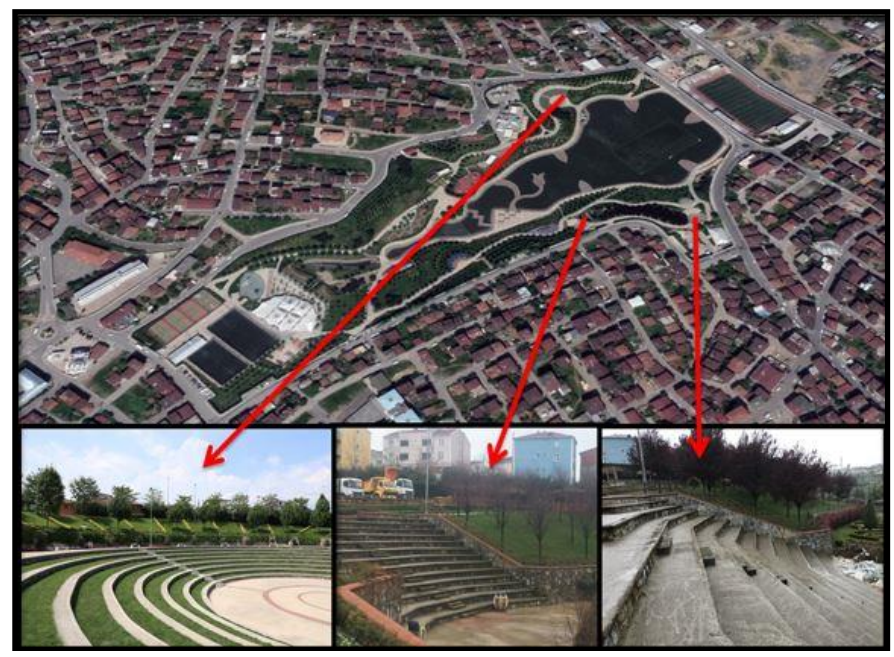

Şekil 15: Sultanbeyli Gölet Parkındaki amfi tiyatrolar.

Sosyal tesis, LEED yeşil bina kriterlerine göre yeniden yapılandırılmalıdır. Bina bünyesinde kentsel 1sı etkisini azaltan yeşil çatı sistemleri, su tüketimini azaltan atık suyun arıtılmasına yönelik sistemler oluşturulmalıdır.

Park genelinde katı atıkların ayrıştırılarak toplanmasına yönelik sistemler geliştirilmelidir.Ayrıştırma işlemlerinde; cam, kağıt, organik artıklar gibi atıkların ayrı ayrı geri dönüşüm ayrımları bulunmalıdır.

Dış mekan kentsel donatı elemanlarıyla yağmur suyu depolayan ve depolanan yağmur suyunun alan içinde kullanan sistemler getirilmelidir. Klasik ahşap bankların yerine doğala yakın görüntüsüyle gabyon oturma birimleri oluşturulmalıdır. Ağaç altı ızgaralar geçirimli betondan, korten çelikten ya da delikli tipte döküm olarak tercih edilebilir.

Aydınlatmalarda, düşük enerji tüketimi olan Led ampuller kullanılmalıdır. Fotovoltaik panelli aydınlatma sistemleri, gün boyunca güneş enerjisinin bataryasında depolamaktadır. Akşam saatlerinde bataryada depoladığ 1 elektriği kullanarak aydınlatmaktadır. Bisiklet yolu içinde güneş panelleri düşünülerek, elektrik tasarrufu sağlanmalıdır. 
Sultanbeyli Gölet Parkında yürüyüş yolu süpürgeli betondur. Ana aksta; geçirgen beton plak taşlar, geçirimli beton ve gözenekli asfalt vb. malzemeler kullanılabilir. 1m kadar genişlikte kıvrımlı tali akslarda; çakıl veya kalın bir malç katmanı oluşturulabilir.

\subsubsection{Bitkisel Tasarımda Tespit Edilen Sorunlar ve Çözüm Önerileri}

Sultanbeyli Gölet Parkında çim yüzeyler $\left(55.000 \mathrm{~m}^{2}\right)$ geniş bir alan kaplamaktadır. Bu da alanın yaklaşık \%40’1 kadardır. Özellikle, tüm şevlerde çim kullanılmıştır. Su tasarrufu sağlamanın en etkili yolu, çim alanları azaltmaktır. Şevlerde toprağı tutacak türler ve yer örtücüler kullanılmalıdır. Alanın oldukça eğimli yapısı toprak tutucu bitki türlerine gereksinim duymaktadır. Şev alanlarda toprağı tutacak türler; Damkoruğu (Sedum spp.), Dağ muşmulası (Cotoneaster spp.), Ardıç türleri (Juniperus spp.), Sabır bitkisi (Agave spp.), Yukka (Yucca spp.), Buz Çiçeği (Mesembryanthemum) Türleri, Katır Tırnağı (Cytisus spp.), Ateş Dikeni (Pyracantha spp.), İğde (Elaeagnus spp.), Kadın Tuzluğu (Berberis spp.) vb. tercih edilmelidir.

Su tüketimini azaltacak kurakçıl peyzaj alanları oluşturulmalı, bitkilerin su tutma kapasitesini arttıran malçlama gibi yöntemler (ağaç kabukları, kalın talaş, curüf, mıcır, pomza vb.) ağaç ve çalı diplerinde uygulanmalıdır (Çorbacı vd., 2011).

Proje kapsamında; 4000 adet ağaç, 85.000 adet çalı, 1.500 .000 adet mevsimlik dikilmiştir (Şekil 16). Kullanılan ağaçların büyük çoğunluğu ithaldir ve Q40-45 gövde çapındadır. İthal bitki türlerinin alana adapte olması için ek bakım ve su ihtiyacı gerekmektedir. Bölgeye özgü doğal türler kullanılmalıdır. İthal türlere göre bakımları daha kolaydır ve kimyasal gübre ilaç kullanımı da azdır.
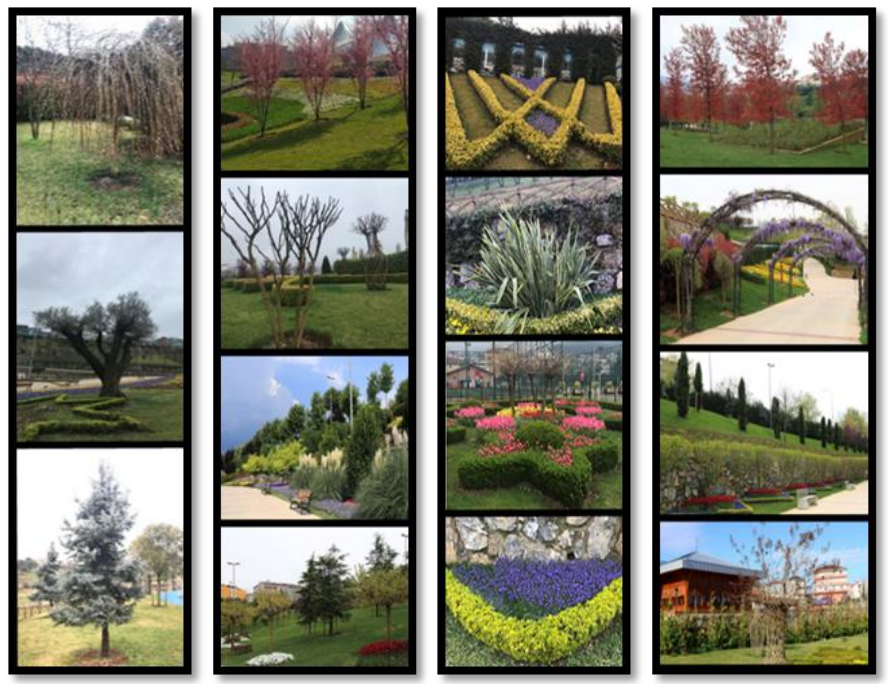

Şekil 16: Sultanbeyli Gölet Parkının bitkisel uygulamasında kullanılan bazı türler.

Alanda mevsimlik bitki grupları çok fazladır ve farklı renklerde olduğu için görsel karmaşa oluşturmaktadır. Bitki gösteri alanlarında su isteyen mevsimlikler yerine perennial bitki türleri ile yer örtücüler kullanılmalıdır.

Alanda biyolojik çeşitliliği ve sürekliliği sağlamak için koku bahçesi oluşturulmalıdır. Biberiye (Rosmarinus officinalis L.), Adaçayı (Salvia officinalis L.), Lavanta (Lavandula angustifolia Mill.), Kekik (Thymus vulgaris L.), Mercan köşkü (Origanum vulgare.), Oğul otu (Melissa officinalis L.) gibi türler kullanılmalıdır.

Alanın devamında yapısal ve bitkisel dengenin ekoloji temelli kaynaklarından birini oluşturan hobi bahçeleri oluşturulmalıdır.

\subsection{Sultanbeyli Gölet Parkı İçin Sürdürülebilir Kriterler Doğrultusunda Oluşturulan Tasarım Modeli}

Sultanbeyli Gölet Parkı için gözlemlenen problemlere yönelik getirilen çözüm önerileri ile bir tasarım oluşturulmuştur. Oluşturulan fonksiyonların ortak noktası, sürdürülebilir malzeme kullanılarak yapılmış olmasıdır. Tasarımda geçirimsiz sert zeminler ve çim alanlar azaltılmıştır. Alanın konumu ve arazi koşulları el verdiği sürece enerji ve su etkin tasarıma yönelik çözümler getirilmiştir. Tasarıma zemin oluşturan alan kullanım paftası Şekil 
17'de verilmiştir. Projenin ana hatları üzerinde yapılan bu değişiklikler Tablo 2'de mevcut tasarımla karşılaştırılmıştır.

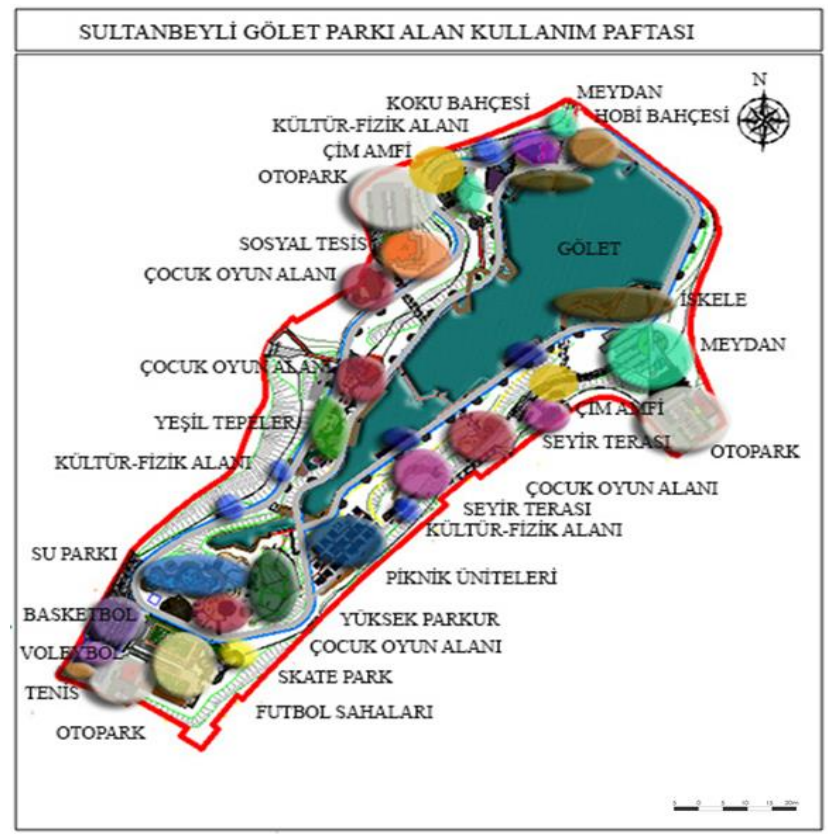

Şekil 17: Sultanbeyli Gölet Parkı için oluşturulan alan kullanım paftası

Tablo 2: Mevcut ve oluşturulan tasarım için sert ve yumuşak peyzaj karşılaştırması

\begin{tabular}{|c|c|c|c|}
\hline MEVCUT TASARIM & ALAN & OLUŞTURULAN TASARIM & ALAN \\
\hline Geçirimsiz yüzey (Yollar) & $16.500 \mathrm{~m}^{2}$ & Geçirimli yüzey (Yollar) & $12.300 \mathrm{~m}^{2}$ \\
\hline Fonksiyonlar & $25.200 \mathrm{~m}^{2}$ & Fonksiyonlar & $23.400 \mathrm{~m}^{2}$ \\
\hline Ăgaç, Çalı ve Yerörtücü & $7.300 \mathrm{~m}^{2}$ & Ağaç, Çalı ve Yerörtücü & $46.300 \mathrm{~m}^{2}$ \\
\hline Çim & $55.000 \mathrm{~m}^{2}$ & Çim & $22.000 \mathrm{~m}^{2}$ \\
\hline TOPLAM & $104.000 \mathrm{~m}^{2}$ & TOPLAM & $104.000 \mathrm{~m}^{2}$ \\
\hline
\end{tabular}

Sultanbeyli Gölet Parkında mevcut tasarım ile oluşturan tasarım karşılaştırıldığında, çim alanların \%40 oranında azaldığı görülmektedir. Çim dışındaki yumuşak peyzaj alanları (ağaç, çalı ve yer örtücü türlerin dikimi, kurakçıl peyzaj alanları, malçlama uygulamaları ve yağmur bahçeleri uygulaması için) yaklaşık olarak 6-7 kat arttırılmıştır. Sert zeminler olabildiğince azaltılmaya çalışılmıştır. Oluşturulan fonksiyonlarda ve yürüyüş yollarında, sürdürülebilir malzemelerin kullanılmasına özen gösterilmiştir (Tablo 3).

Tablo 3: Mevcut ve oluşturulan tasarım için kullanılan malzemeler

\begin{tabular}{lll}
\hline FONKSIYON & MEVCUT TASARIM & OLUŞTURULAN TASARIM \\
\hline Ana aks (Yürüyüş yolu) & Süpürgeli Beton & Geçirimli Beton \\
Tali aks (1m) & Mozaikli Beton & Geçirimli Parke Taş, Malçlama \\
Bisiklet yolu & Süpürgeli Beton & Güneş paneli \\
Çocuk Oyun Alanı & Dökme Kauçuk & Doğal Materyaller \\
Kültür-Fizik Alanı & Dökme Kaçuk & Doğal Materyaller \\
Su parkı & Dökme Kauçuk & Doğal Materyaller \\
Gölet üzeri ahşap teraslar & Kompozit Ahşap & Kompozit Ahşap \\
Skate Park & Süpürgeli Beton & Geçirimli Beton \\
Otopark & Süpürgeli Beton & Gözenekli asfalt, Ekogrid \\
Amfi Tiyatro & Mozaikli Beton & Kireç taşı \\
Sosyal Tesis & - & Yeşil Çatı \\
IBB Gölet Spor Tesis Binası & - & Yeşil Çatı \\
IBB Şeflik Binası & - & Yeşil Çatı \\
\hline
\end{tabular}




\section{Tartışma ve Sonuç}

Sürdürülebilirlik kavramının Türkiye'deki durumu incelendiğinde, son dönemde konuyla ilgili özellikle akademik düzeyde yapılan çalışmaların hız kazandığı ancak, yönetimler düzeyinde konuya yeterli önemin verilmediği görülmektedir. Günümüzde sürdürülebilirlik çalışmaları ikinci planda tutulduğu için oluşturulan projelerde söz edilecek düzeyde bir gelişme gözlenmemiştir. Yurtdış1 örnekleri incelediğinde ise konuyla ilgili birçok yasa, destek ve çevre dostu uygulamaları ödüllendiren sertifika sistemlerinin bulunduğu ve yapılan uygulamaların sertifika kriterlerini karşılayacak düzeyde olduğu gözlemlenmektedir.

Şehirlerde giderek artan nüfus ile birlikte yapılaşma da artmıştır. Günlük hayatın yoğun temposu, kapalı mekanlarda geçen uzun çalışma saatleri sebebiyle insanlar günlük işlerini bırakıp nefes almak istediklerinde yeşil alanlara gereksinim duymaktadır. Bu sebeple, var olan yeşil alanların gelecekte de kullanılabilmesi için korunması ve alan içindeki fonksiyonların çevreye zarar vermeyecek şekilde oluşturulması gerekmektedir. Kent içlerinde oluşturulan yeşil alanlar, kendi enerjisini kendi karşılamalı aynı zamanda da çevreye fayda sağlamalıdır. Yenilenebilir enerji kaynaklarını destekleyen uygulamalara yer verilmesi, su ve enerji etkin çözümler getirilmesi, bu alanlarda sürdürülebilirliğin sağlanması yönünde büyük bir adım atılmasını sağlayacaktır.

Çalışma kapsamında, araştırma alanının yapısal ve bitkisel tasarımında tespit edilen sorunlar ve sürdürülebilir tasarım ilkeleri doğrultusunda getirilen çözüm önerileri ile yeniden oluşturulan Sultanbeyli Gölet Parkı, kendi kendine yetebilen enerji etkin bir parka dönüştürülmüştür. Araştırma alanının mevcut tasarımı, ekolojik çözümler ve su-enerji etkin uygulamalarla geliştirilmiş, yeni bir tasarım modeli oluşturulmuştur.

Büyük bir kısmı şev alanlarından oluşan alan için mevcut kotlara en uygun şekilde oturacak tasarım çözümleri oluşturulmuştur. Gereksiz kazı-dolgudan kaçınılmış, toprağı tutacak teraslama sistemleri ile yeşil alanlardaki toprağın kayması önlenmiştir. Bununla beraber, toprağı tutacak bitki türleri önerilerinde bulunulmuştur. Genel anlamda alanın doğal vejetasyonu korunmuştur. Geniş yüzeyleri kaplayan çim alanlar azaltılarak sadece park girişinde göz önünde olan bölümlerde çim kullanılmıştır. Alanın mevcut bitki listesinde bulunan ithal türlerin yerine alana kolay adapte olabilecek doğal türlerin kullanılması önerisi getirilmiştir. Sadece çim alanlarda sprink sulama kullanılması, diğer yumuşak peyzaj kısımlarında bulunan ağaç, çalı ve yer örtücü grupların sulanması için ise damlama sulama sistemi uygun görülmüştür. Çim alanların dışında yumuşak peyzaj alanları için getirilmiş kurakçıl peyzaj uygulamaları ile alandaki su etkinliğinin arttırılması amaçlanmıştır. Geçirimsiz sert yüzeylerin önünde oluşturulacak yağmur bahçeleri yüzeysel akışı hızlandıracağı için, özellikle otopark önlerindeki yeşil parseller yağmur bahçesi oluşturmak için bırakılmıştır. Bitki diplerinde önerilen malçlama uygulamaları gerek torf, ağaç kabuğu, kozalak gibi organik olarak; gerekse çakıl, mıcır gibi inorganik malzemelerin kullanımı ile topraktaki nemin tutularak su kaybının azaltılmasını sağlayacaktır. Oluşturulan tasarımda bakım da önemli bir konudur. Bitkinin uzun ve sağlıklı yaşaması için gerekli dönemlerde budalama ve gübreleme işlemi yapılması alanda maliyeti düşürecektir. Geri dönüşüm kutularından elde edilecek kompost, bitkilerin gelişimi için faydalı olacaktır.

Alanın mevcut tasarımı, su ve enerji etkinliği bakımından ele alındığında, su etkin tasarım açısından bazı çözümler getirildiği görülmektedir. Gölet aynı zamanda bir su toplama havzası içinde olduğundan, sulamada şebeke suyuyla beraber kullanılmaktadır. Alanda iki adet su deposu bulunmaktadır. Bu da tüm alan için yeterli değildir. Hazırlanmış olan tasarım projesinde, 25 tonluk 3 adet su deposu alanın su ihtiyacını karşılayacak kapasitededir. Gerekli durumlarda şebekeden de su kullanılacaktır. Araştırmanın çalışma konusu, Sultanbeyli Gölet Parkının sürdürülebilirliğinin sağlanması amacıyla, su ve enerji etkin peyzaj tasarımı kapsamında çözüm önerileri getirmek olduğundan, alan birçok açıdan ele alınmıştır.

Yapısal anlamda irdelendiğinde; Sultanbeyli Gölet Parkının mevcut tasarımının, geçirimsiz yüzeylerden oluştuğu ve çok fazla sert zemin bulunduğu görülmektedir. Geçirimsiz yüzeylerin alanda büyük sıkıntılara neden olduğu görülmüştür. Birçok yerde yağmur 1zgaraları yüzeysel akışı karşılayamamaktadır ve bazı bölgelerde yer yer su birikintilerine neden olduğu görülmektedir. Çözüm olarak; yürüyüş yolları, otoparklar ve diğer tüm fonksiyonlarda suyu toprağa kolay geçirecek malzemeler tercih edilmiştir. Bu kapsamda; geçirimli beton, gözenekli asfalt, geçirimli - kil esaslı ya da kompozit malzemeden oluşturulan parke taşları kullanılmıştır. Bu malzemeler, yağmur suyunun ve sulama suyunun toprağa karışmasına izin verir, bu da kirletici maddeleri temizler ve peyzajdaki akış1 azaltır. Doğal granit, bazalt ve kayrak gibi taşlarda derz aralığı, geçirimli malzeme ile oluşturulursa bu soruna çözüm olacaktır. Ahşap yüzeylerde kompozit ahşap kullanmak iyi bir çözümdür. Diğer türler için de sertifikası olan malzemeler değerlendirilmelidir. 
Enerji etkin uygulamalarda alanın konumu göz önünde bulundurularak güney cephelerde fotovoltaik panellere yer verilmiştir. Elde edilen elektrik enerjisi, alanın içinde bulunan yapılarda, süs havuzlarının çalışmasında ve sıcak su elde etmek amacıyla kullanılmıştır. Aydınlatma sisteminde oluşturulan güneş panellerinin gündüz akülerinde şarj ettiği elektriğin gece parkı aydınlatmak için kullanılması amaçlanmıştır. Su etkinliği olarak ise, gri suyu ve yağmur suyunu geri kazandıran arıtma sistemleri oluşturulmuştur. Alandaki süs havuzunda ve su parkından yağmur suyu geri kazanımından faydalanılmıştır. Aynı şekilde yapı içlerindeki tuvaletlerde de geri dönüştürülen su ile şebeke suyunun tüketimi azaltılmaya çalışılmıştır. Yapılarda ısı ada etkisini kırmak adına yeşil çatılar oluşturulmuştur.

Sultanbeyli Gölet Parkına getirdiğimiz bu öneriler ile alanın sürdürülebilir ve enerji etkin bir parka dönüştürülmesi sağlanmıştır. Fakat, sürdürülebilir alanların oluşturulması, ekonomik maliyetlerin yanında farklı birçok etkene dayanmaktadır. Sürdürülebilir ilkelerin sağlanması için belli bir hizmet süresi geçmesi gerekmektedir. Oluşturulan alanlar kendini yenilediğinde ve alanla uyumlu hale geldiğinde, zamanla olumlu sonuçları görülmeye başlanacaktır. Yukarıda verdiğimiz öneriler dikkate alınarak bundan sonra yapılacak parklarda bir model olması amaçlanmıştır (Şekil 18).

Çevresel sürdürülebilirliğin sağlanmasında peyzaj projelerinde enerji etkin tasarımlar dikkate alınmamaktadır. Arazi kullanımı, yenilenebilir enerji kaynaklarından yararlanılması, geri dönüştürme ve atık yönetimi gibi önemli konular maliyet analizleri düşünülerek, ikinci plana atılmaktadır. Bize getirisinin mevcut olandan çok daha fazla olacağı düşünülmemektedir. Ülkemizde bu tip uygulamalar yaygınlaştıkça ve yapılan araştırmalar çoğaldıkça oluşacak çevre bilinciyle enerji etkin projeler önem kazanacaktır.

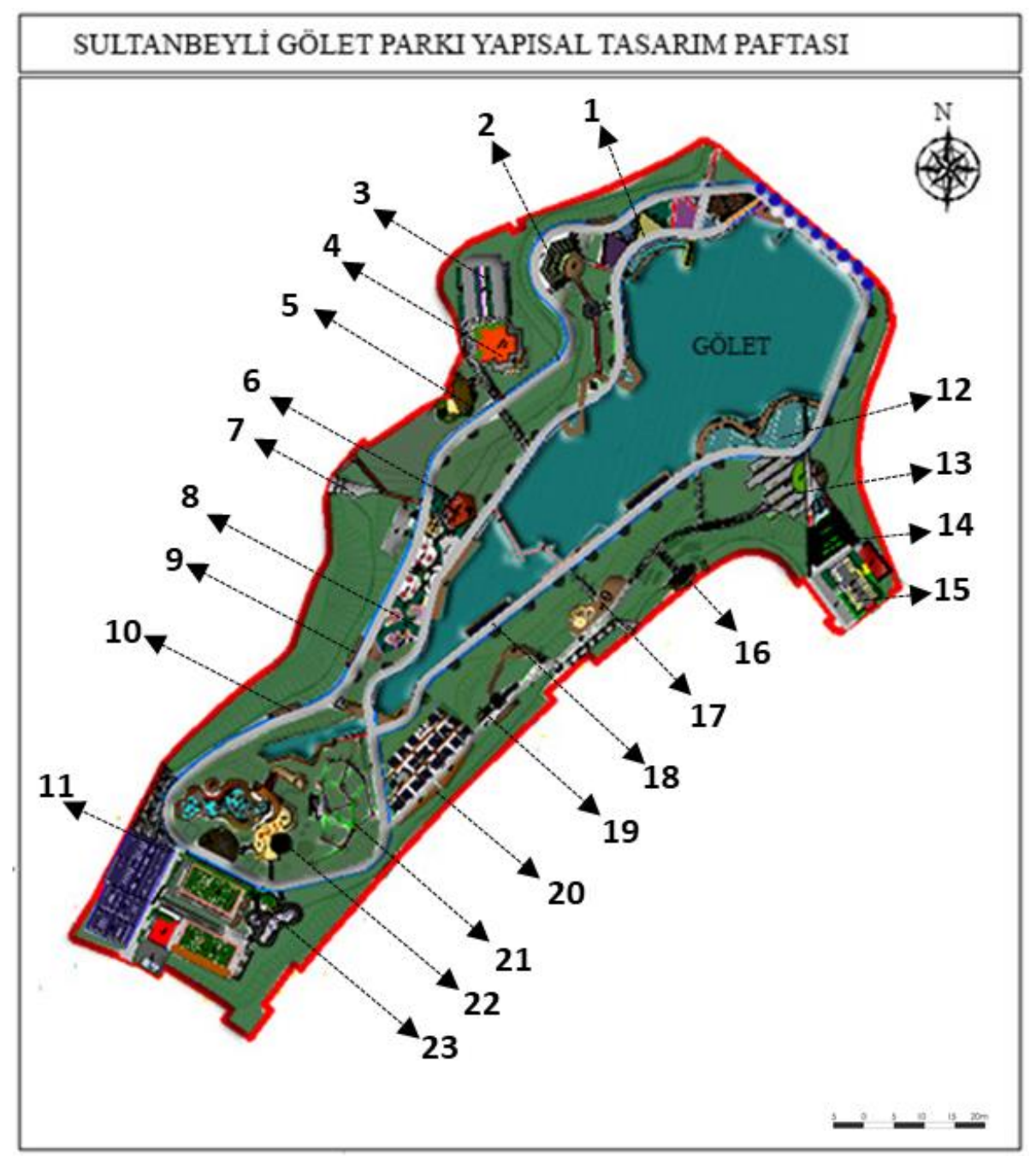

Şekil 18: Sultanbeyli Gölet Parkı için oluşturulan sürdürülebilir tasarım modeli 


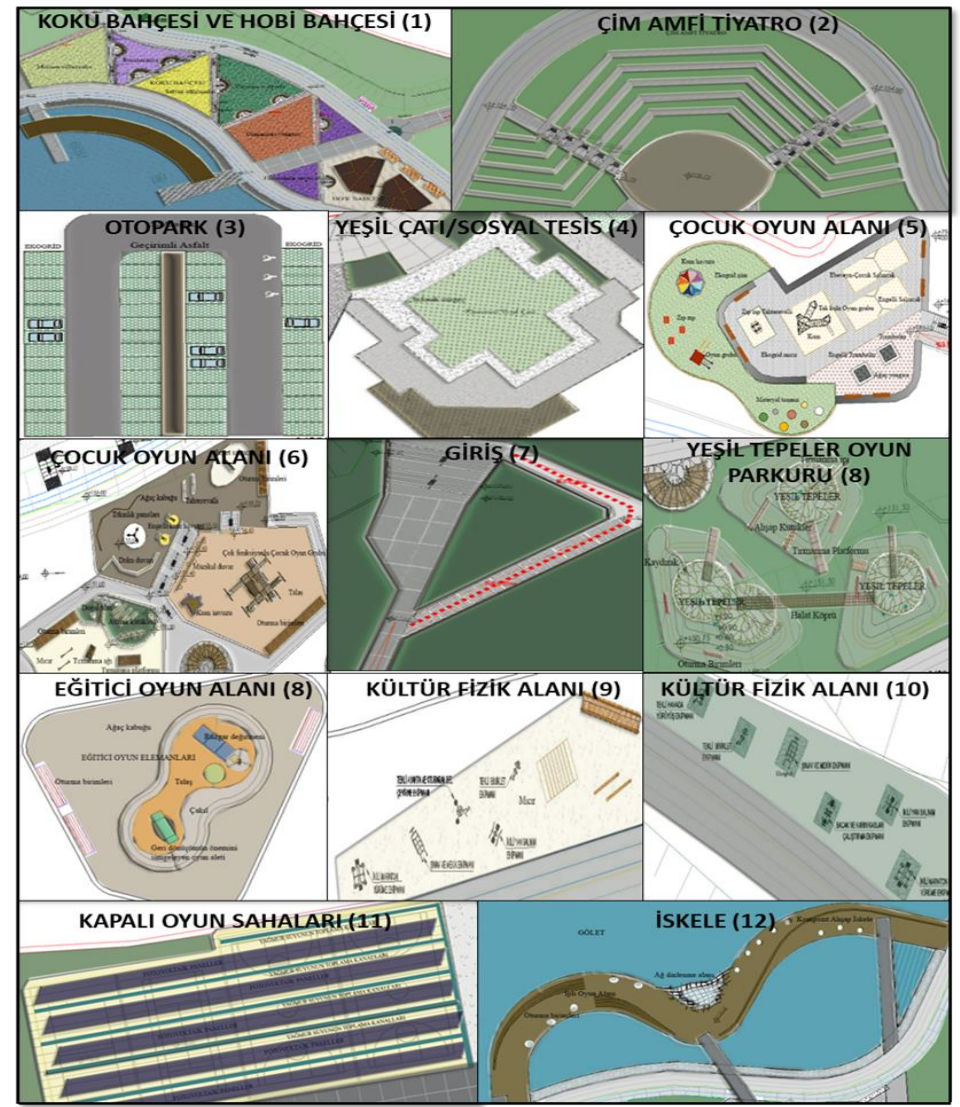

Şekil 19: Sultanbeyli Gölet Parkının sürdürebilirlik kriterlerine göre tasarlanan fonksiyonları.

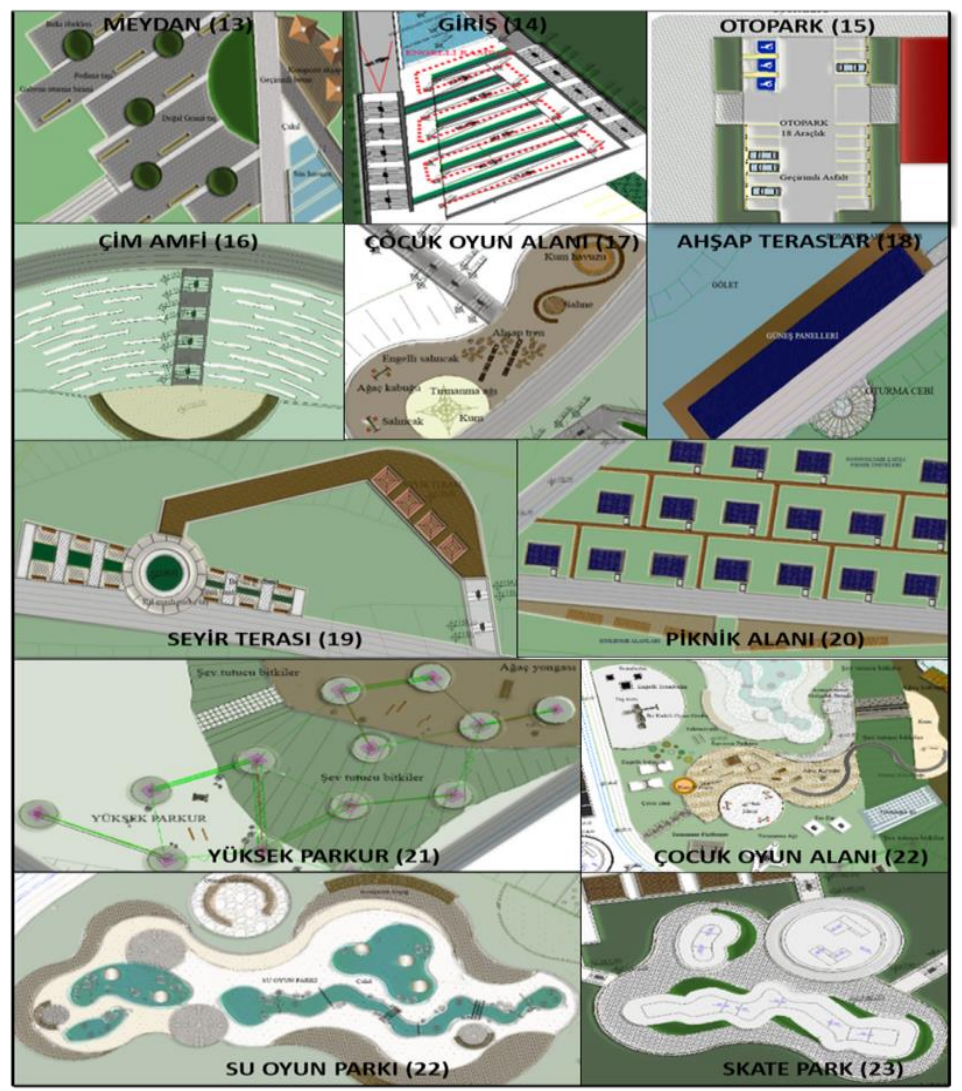

Şekil 19 (Devamı): Sultanbeyli Gölet Parkının sürdürülebilirlik kriterlerine göre tasarlanan fonksiyonları 


\section{Teşekkür}

Bu çalışma, İstanbul Üniversitesi-Cerrahpaşa, Lisansüstü Eğitim Enstitüsü, Peyzaj Mimarlığı Anabilim Dalı’nda tamamlanmış "Sürdürülebilir Peyzaj Tasarım Kriterleri Doğrultusunda Sultanbeyli Gölet Parkı için bir Model Önerisi” adlı Yüksek Lisans Tezinden üretilmiştir.

\section{Kaynaklar}

1. Atıl, A., Gülgün, B., ve Yörük, İ., (2005). Sürdürülebilir Kentler ve Peyzaj Mimarlığı, Ege Üniversitesi, Ziraat Fakültesi Dergisi, 42(2), 215-226.

2. Ciravoglu, A., (2006). Sürdürülebilirlik Düşüncesinde Mimarlığın Yeri Üzerine Alternatif Bir Yaklaşım: Mekansal Örüntünün Çevre Bilincine Etkisi, Doktora Tezi, Yıldız Teknik Üniversitesi, İstanbul.

3. Çorbacı, Ö.L., Ertekin, M. ve Özyavuz, M., (2011). Kurak ve Yarı Kurak Alanlarda Kurakçıl Peyzaj Uygulamaları, Kurak ve Yarı Kurak Alan Yönetimi Çalıştayı, 5-8 Aralık 2011.

4. Durmuş Arsan, Z., (2009). Enerji Etkin Mimarlık Yaklaşımları Üzerine Bir Eleştiri. Dosya: Bir Tasarım Konusu Olarak Enerji Etkin Mimarlık, Ege Mimarlık Dergisi, Sayı: 68, Ocak, sf.18-24, TMMOB Mimarlar Odası İzmir Şubesi, İzmir.

5. Erkan, Ö., (2011). Çocuk Oyun Parklarında Modül Tasarımında Ahşap Plastik Kompozit Malzemenin Kullanım Olanakları. Yüksek Lisans Tezi, İstanbul Kültür Üniversitesi/Fen Bilimleri Enstitüsü/İç Mimarlık Bölümü/İç Mimarlık ve Çevre Tasarımı Anabilim Dalı, İstanbul.

6. Gürbey, A.P. ve Kanbur, N., (2020). Hospital Landscape Sustainability, In Theory and Practice in Sustainable Planning and Design, Planning, Design, Applications, Ed. Özyavuz M., Peter Lang, Berlin, pp.651-676.

7. Gürbey, A. P., (2020). Landscape in LEED-Certified Buildings: What Matters Most, Aesthetic Concerns or Sustainability?, In Advances in Scientific Research: Engineering and Architecture, Ed. Christov I., Krystev V., Efe R., Gad A.A., St. Kliment Ohridski University Press, Sofia, pp. 83-100.

8. İBB (2005). Planlama ve Daire Başkanlığı Şehir Planlama Müdürlüğü, İ Nazım İmar Planı Analitik Etüdler İ̧̧i, Özel Teknik Şartname No:5-7 Gelişme Eğilimleri Finansman Analizi, Bütüncül Yer Seçim Kararları, 5.7.9, Açık Alan Yetersizlik Raporu, Aralık 2005.

9. İBB (2006). İstanbul Metropoliten Alanında Doğal Kaynaklar: Yer Bilimleri/Tarım alanları ve Toprak/Orman alanları ve Ekoloji/Yeraltı kaynakları ve Çevre Sorunları, Metropoliten Planlama ve Kentsel Tasarım Merkezi.

10. Keskin, D., (2018). Sürdürülebilir peyzaj alanları ve SITES sertifikası, 26 Aralık, İstanbul https://www.erketasarim.com/surdurulebilir-peyzaj-alanlari-ve-sites-sertifikasi (18.04.2019)

11. Küçükyağcı, P. Ö., Atasayan, Ö. ve Oktay, S. Ö. (2015). Çocuk Oyun Alanı Tasarımlarında Sürdürülebilirlik, 2. Uluslararası Sürdürülebilir Yapılar Sempozyumu, 28-30 Mayıs, Ankara.

12. Özdemir, A., (2017). Engelsiz Oyun Alanları İçin Kapsayıcı Tasarım Yaklaşımı, Ege Mimarlık Dergisi 2017/1 (95), 20-23. http://egemimarlik.org/95/5.pdf (02.03.2019)

13. Öztürk, M., (2017) Su Geçiren Beton ve Asfaltlar, Çevre ve Şehircilik Bakanlığ http://www.cevresehirkutuphanesi.com/assets/files/slider_pdf/248HQ7HaxmKA.pdf (05.02.2018)

14. Pitts, A. (2004). Sustainability and Profit. Architectural Press, Imprint of Elsevier, Oxford.

15. Saygın, N. (2017). Sürdürülebilir Yağmursuyu Yönetimi ve Enerji, İzmir Bölgesi Enerji Forumu, İzmir Mimarlık Merkezi, 7-8 Nisan 2017, İzmir.

16. Şermet, R. (2017). Sürdürülebilir Peyzaj Tasarımlar için Sertifikasyon Sistemlerinin Değerlendirilmesi, Yüksek Lisans Tezi, Namık Kemal Üniversitesi, Fen Bilimleri Enstitüsü, Tekirdağ.

17. Taştepe, T., Başbay, A.M. ve Yazıcı, Z. (2016). Kent Merkezlerindeki Ekolojik Temelli Oyun Alanlarının Mekansal Açıdan İncelenmesi: Ankara-Antalya Örneği, Tekirdă̆ Ziraat Fakültesi Dergisi, 13(2), 85-95.

18. Tezer, A. (2015). Ömerli Havzası'nda Ekosistem Servislerine Dayalı Bütünleşik Havza Yönetim Planının Geliştirilmesi Projesi Araştırma Raporu. (İTÜ, İstanbul Kalkınma Ajansı), Proje No: TR10/14/DFD/0039.

19. Tuncay, H. E., (2017). Kentsel Drenaj ve Kent Ekolojisi. İstanbul Teknik Üniversitesi, Mimarlık Fakültesi, Peyzaj Mimarlığı Bölümü, http://www.skb.gov.tr/wp-content/uploads/2017/11/HayriyeESBAH-TUNCAY.pdf (05.01.2019)

20. Türkan E.E. ve Önder, S. (2011). Balıkesir Kenti Çocuk Oyun Alanlarının İrdelenmesi, Tekirdağ Ziraat Fakültesi Dergisi, Cilt 8, Sayı 3, 69-80.

21. URL-1(2018).

http://www.anadoluparkbahceler.com/projeler.php?kategori=Tamamlanan\&baslik=Sultanbeyli\%20G\% C3\%B6let\%20Park\%C4\%B1\%20Peyzaj\%20Projesi\&no=88 (04.04.2018) 
22. URL- 2 (2018). http://webgis.sultanbeyli.bel.tr/keos/ (04.04.2018)

23. URL-3 (2018). http://www.sultanbeyli.istanbul/haberler/baskan-keskin-goleti-yakinda-hizmeteaciyoruz\#galeri[haber $] / 1 /(04.04 .2018)$

24. URL-4 (2018). http://www.ibb.gov.tr/tr-TR/HaberResim/21838/golet\%20eski\%20hal\%20(3).JPG $(05.04 .2018)$

25. URL-5(2018).

http://www.anadoluparkbahceler.com/parklarimiz.php?ilce=Sultanbeyli\&park=Sultanbeyli\%20G\%C3 \%B6let\%20Park\%C4\%B1\&no $=230(04.04 .2018)$

26. URL-6 (2018). http://www.akmyapi.com.tr/Projeler/Tamamlanmis-Projeler/Sultanbeyli-Golet) $(05.04 .2018)$

27. URL-7 (2018). https://www.fatherly.com/play/why-some-playgrounds-are-amazing-most-are-lame-andwhat-to-do-about-it/\#03dbd (11.05.2018)

28. URL-8 (2019). http://www.kavakyolu.bel.tr/erzincan-kavakyolu-belediyesi-vasgirt-deresi-projesi2/\#prettyP (21.02.2019)

29. Yaşar, Y. ve Düzgüneş, E. (2013). Peyzaj Tasarımına Sürdürülebilirlik Kavramının Entegrasyonu: Bir Stüdyo Çalışması, Inönü Üniversitesi Sanat ve Tasarım Dergisi, ISSN: 1309-9876 E-ISSN: 1309-9884 Cilt/Vol. 3 Say1/No.7, 31-43.

30. Yoneda, Y. (2013). Hunter's Point South Waterfront Park and Urban Beach Opens Today in Long Island City. https://inhabitat.com/photos-hunters-point-south-waterfront-park-and-urban-beach-opens-todayin-long-island-city/ (19.06.2018)

31. Yurtsev, A. (2015). Sürdürülebilir Mimarlık Kapsamında Enerji Etkin Peyzaj Tasarım Yaklaşımları, Yüksek Lisan Tezi, Ege Üniversitesi, Bornova, İzmir. 